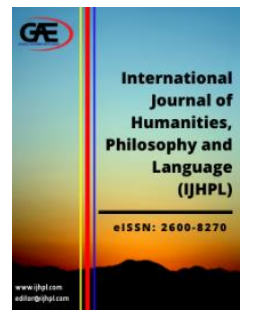

International Journal of Humanities, Philosophy and Language (IJHPL)

Journal Website: http://ijhpl.com/ eISSN: 2600-8270

\title{
COMPREHENSION STRATEGIES OF LITERARY TEXTS USED BY UNIVERSITY OF JORDAN LITERATURE STUDENTS
}

\author{
Yasmeen Almadani ${ }^{*}$, Mohd Nazri b. Latiff Azmi ${ }^{2}$, Khalid Alsmadi ${ }^{3}$ \\ 1 Faculty of Languages and Communication, Universiti Sultan Zainal Abidin \\ Email: E.1_2@live.com \\ 2 Faculty of Languages and Communication, Universiti Sultan Zainal Abidin \\ Email: mohdnazri@unisza.edu.my \\ 3 English Language, Prince Sattam Bin Abdul-Aziz University \\ Email: smadi_khalid@yahoo.com \\ Corresponding Author
}

\section{Article Info:}

Article history:

Received date: 12.04 .2020

Revised date: 28.04 .2020

Accepted date: 29.04.2020

Published date: 10.06.2020

\section{To cite this document:}

Almadani, Y., Azmi, M. N. L., \& Alsmadi, K. (2020). Comprehension Strategies Of Literary Texts Used By University Of Jordan Literature Students. International Journal of Humanities, Philosophy and Language, 3 (10), 45-56.

DOI: $10.35631 /$ IJHPL.310005.

\begin{abstract}
:
Reading plays a significant role in our daily lives. Literary readers build their worlds and expand their imagination with deviating from the literal words to create images that make sense to them in the unfamiliar places the texts describe. This study examined the most useable strategies among English language and literature students at the University of Jordan as well as whether there are significant differences between males and females in this regard. Methodology: This study employed both descriptive and quantitative approaches to collect data. The sample was selected using simple random sampling. The sample of the study was 120 EFL bachelor students divided into 60 males and 60 females from UJ. SPSS program was used in the data analysis. The research instrument was a questionnaire designed by the researcher in accordance with the study questions. SPSS social package was used to treat the collected data through multiple regression, T-test, and descriptive analyses. Result: The data analysis showed that the most usable strategies were personal growth model, cooperative learning, intensive reading, illustration, cultural model, but that doesn't mean those are the most effective on the reading ability of literary texts. It also indicated that there are only significant differences in the use of the cultural model and the personal growth model but there aren't any significant differences in the usage of the other mentioned strategies. Conclusion: It is recommended that the decision-makers should pay more attention to the literary texts that are provided to the university students while deciding the bachelor's syllabus. So that they should organize literary texts in combination with the most effective reading strategies. To help them to get rid of the expected difficulties of comprehending such texts. This study contributes to supply the future bachelor syllabuses planning of English language and literature department at the University of Jordan and other universities around.
\end{abstract}




\section{Introduction}

The literary text is defined as a piece of artwork of a written material that enables writers to express their feelings, and what goes on inside their minds. This is evident in the various literary texts, whether it is a story, a novel, poetry in all its forms, an article, or a play. Whereas reading comprehension is a process of interaction between readers and what they bring to the text, such as their prior or background knowledge and strategy use. The aim of reading literary texts is to look at the writers' creativity in their texts, the beauty in these texts, the emotions and literary artistic features that affect the readers, and the objective values they contain. So, it is considered a cognitive system which is based on knowledge as well as psychological and emotional aspects (Gray and Schunn, 2019).

As cited in (Marashi and Rahmati, 2017) Brantmeier defines reading strategies as the comprehension processes that readers use in order to make sense of what they read. That are categorized as approaches, actions, and procedures used to improve reading comprehension.

Since literature is a reading-centered activity and most EFL learners face comprehension problems while reading literary texts, proficient readers would overcome these problems by applying effective reading strategies to solve the comprehension challenges (Almutairi, 2018). Kuru and Gonen (2015) state that reading strategies are very important to help the reader comprehend the text in the process of reading. The goal of reading strategies is to teach students how to make sense of the literary texts they have to read during their bachelor's yeas.

\section{Statement of the Problem}

The ability to read literary texts with understanding is an essential skill to English language and literature students. They continually claim and complain mainly after any piece of literary reading is assigned. When students struggle to read, reading becomes discouraging and students avoid reading. Thus, reading comprehension is affected badly (Fujino, 2017). students' lack of reading comprehension strategies is also considered as a major cause of students' poor comprehension skills (Al-Ghazo,2016).

The researcher observed that many students are weak in comprehending literary pieces of the bachelor syllabus. In other words, they spend a lot of time to understand the literary work that they are supposed to prepare for the lecture. The researcher also observed that many of them based on different strategies to achieve high recognizing of these kinds of texts. The researcher concluded that training students on the use of reading strategies is very effective to improve the quality of their reading comprehension of the literary texts. Thus, the current study seeks to identify the most usable strategies among literature students at the University of Jordan in order to inform instructional practice in their reading of literary texts.

\section{Purpose of the Study}

This study aims at identifying and describing the most usable strategies by English language and literature students at the University of Jordan. Specifically, to overcome the strategies they use in reading the literary texts that are involved in their bachelor syllabus. So, this research 
highlights the strategies that the participant base on during their bachelor's years to understand literary texts deeply.

\section{Research Questions}

The study strives to answer the following questions:

1.What are the most usable strategies that students based on to deal with the literary texts of their bachelor syllabus in order to achieve the best reading comprehension?

2. Are there any statistically significant differences between male and female in their use of the mentioned strategies in order to achieve the best reading comprehension of their bachelor syllabus literary texts?

\section{Hypothesis:}

- Males don't rely on reading strategies to understand literary pieces.

- Females depend on active and cooperative learning to achieve maximum comprehension of literary texts.

\section{English Language and Literature Bachelor Syllabus's Literary Texts}

The bachelor syllabus of English language and literature at the University of Jordan contains a lot of literary works. It covers all the historical periods of English literature from the AngloSaxon time to the $20^{\text {th }}$ century. The followings are the literary works covered in this syllabus:

1.Old English literature: (Beowulf epic).

2. The middle literature: (The legend of King Arthur).

(The Knights and The Round Table)

(The Canterbury Tales) Geoffery Chaucer.

(Robin Hood play).

3. Elizabethan Period: (The Faerie Queen) Spenser.

(Astrophel and Stella) Sidney.

(The Spanish Tragedy +Edward III" Thomas Kyd).

(Midsummer Night's, Hamlet, Othello, Macbeth, King Lear" Shakespeare).

(Doctor Faustus) Christopher Marlowe.

4.Restoration Age: (Paradise Lost) John Milton.

5. Augustan Literature: (Iliad and Odyssey).

(Robinson Crusoe) Daniel Defoe.

(Gulliver's Travels) Jonathan Swift.

6. The Age of Sensibility: (Elegy Written in a Country Churchyard) Thomas Gray.

7. Romanticism Age: (Songs of Innocence and Songs of Experience) William Blake.

(The Rime of Ancient Mariner) Samuel Taylor Coleridge.

(Lyrical Ballads) William Wordsworth.

(Ode to a Nightingale) John Keat.

8. Victorian Age: (Oliver Twist) Charles Dickens.

(Wuthering Heights) Emily Bronte.

(The Mayor of Casterbridge) Thomas Hardy.

(The Adventures of Tom Sawyer) Mark Twain.

(Alice's Adventures in Wonderland) Lewis Carroll.

(Widowers Houses) Bernard Shaw.

9. $20^{\text {th }}$ century: (Ulysses) James Joyce.

(The Great Gatsby) F.Scott Fitzgerald

(The secret agent) Joseph Conrad 


\section{Limitations of the Study}

Despite the significance of the study, there are some limitations as follows:

1-This study is limited to the English language and literature students at the University of Jordan.

2- It is also limited to the period of implementation of the study, which took place during the first semester 2019-2020.

3- It is limited to the literary texts that are involved in the bachelor syllabus of English language and literature faculty in University of Jordan.

\section{Related Literature}

Hurriyah(2017)conducted a study aims to clarify how reader identifies the narrative texts through applying intensive reading strategies in English classrooms. The result of this study shows that students do intensive reading to understand all of the contents of the story and to understand the message it conveys. Learning narrative texts using such strategies could improve their skills of comprehending narrative text.

Also, Qamar (2016) conducted a study to shed light on the Effectiveness of Critical Thinking Skills for English Literature Study with Reader Response Theory. The results show that critical thinking is highly valuable for the study of literature as it explicitly asked for learners' beliefs, perceptions, and judgments in order to remove the ambiguity of thought. Perfection of thought can be achieved with the use of critical thinking skills while training of mind needs interaction between literary text and the reader as literature has the capacity to achieve mental traits specified to critical thinking.

Okkinga (2018) and her colleagues conducted a study to investigate how reciprocal teaching can improve low achieving adolescents' reading comprehension in whole classroom settings (as opposed to small group settings) and to what extent intervention effects are dependent on teacher behaviour. Findings show that reciprocal teaching contributed to adolescent low achievers' reading comprehension only when experimental teachers provided high quality strategy instruction.

There are some valuable strategies for improving reading comprehension ability: reciprocal teaching, instructional discussions, visualization, partner reading, multiple reading strategies, assessment, and running records. in the vision of reciprocal teaching, teachers teach learners to predict, summarize, clarify, and ask questions for parts of a text. These strategies have been considered as effective strategies for improving learners' reading comprehension abilities. That is, learners will have stronger reading comprehension skills on their own if lecturers give them mental instruments for understanding a piece (Gilakjani\& Sabouri, 2016).

\section{Methodology}

\section{Research Design}

This study is a descriptive study since it attempts to address the most usable strategies that students based on to deal with the literary texts of their bachelor syllabus in order to achieve the best reading comprehension. SPSS social package was used to treat the collected data through multiple regression, T-test, and descriptive analyses. Thus, this research is considered as descriptive quantitative research. 


\section{Population of The Study}

The population of this study is the English language and literature students at the University of Jordan.

\section{Sample of the Study}

The sample of the study is 120 EFL bachelor students divided into 60 male and 60 females from the Department of English Language and Literature at University of Jordan. Ages of the samples range between 20 to 24 years old. Simple random sampling was used to choose these samples in which each element of the frame has an equal probability of selection and each stratum has to be essentially homogeneous and heterogeneous among themselves.

\section{Data Collection and Mechanism}

The data of the study were elicited via questionnaire designed by the researcher in accordance with the study questions to investigate the respondents' attitudes and opinions. The questionnaire addresses the problematic challenges that remarkably face the students such as the problems related to the process of figuring out the meanings of some old literary words, guessing the meanings of some dead words, distinguishing main ideas from supporting ideas in literary context, the environmental conditions which deter the comprehension of the reading texts, rarity of using the dictionary to look up meanings of difficult words of the literary contexts, lack of training on comprehending the text, and reading the text to pass the required exams instead of enjoying and interacting with it.

\section{Instruments of the Study}

The data of the study were elicited via a questionnaire designed by the researcher in accordance with the study questions to investigate the respondents' attitudes and opinions. Fifth Likert scale was used for student responses. The questionnaire addressed involved items related to critical thinking, active learning, cooperative learning, role playing, illustration, intensive and extensive reading.

\section{Instrument Items:}

The research questionnaire consists of the following items:

*Acting the plays help me completely to understand the drama. (cooperative learning)

*Discussing a piece of literature in small groups allows me to try to analyze the text. (group work)

* I prefer literary works contain illustrations to clarify the content. (illustration)

* I prefer literary works assigned with tasks and activities. (extensive reading)

* I link the information contained in literary texts I read with my prior knowledge and with texts written in my native language? (Critical thinking)

* I find learning about author culture and ideology can help me to better understand of the text's theme and plot. (Cultural model)

* I always try to engage with the text to have more pleasure. (Personal-growth model)

* I sometimes based on reciprocal questions techniques when I read literary texts. (Active learning)

* To get specific information from a literary text I usually read the whole text continuously (intensive reading)

\section{The Validity of The Instrument}

In conformity with validity procedures, the questionnaire was sent to four independent content experts who work as EFL lecturers at Om-Alqura University, where the researcher was working as a part-time lecturer. The content and relevance of the items were checked 
accordingly, the experts assessed whether all the items were relevant for the target, population and the intended purpose of the questionnaire. To judge relevance of each item a four-points scale used. The experts scored each question as follows: $1=$ not relevant, $2=$ somewhat relevant, $3=$ quite relevant, $4=$ highly relevant. And the required modifications related to the strategies involved in the questionnaire were addressed. They asked only to put the expected problems associated with the same idea within one item, such as that the ambiguous phrases and dead vocabulary that should be involved in the same item. Equivalently with the strategies, they asked to group all the related strategies under the main grouping name. For example, the reciprocal strategy is the same field of active learning, and reading the whole text is the same as the intensive reading.

\section{Reliability of the Instrument}

To check the reliability of the instrument, a pilot study was conducted with a sample similar to the actual study samples. Fifteen students responded to the questionnaire to examine the internal consistency of the questionnaire items. Johanson \& Brooks (2010) and Treece (1982) noted that for a project with 100 people as the sample, a pilot study participation of 10 subjects should be a reasonable number. After analyzing the pilot study participants' responses, Cronbach's $\alpha$ internal consistency was found to be 0.73 , which shows that the consistency is high, so the instrument's items are reliable and able to achieve the study's objectives. Taber (2016) states that to consider the instrument reliable to measure the variables and particular objectives, the acceptable value of Alpha must be over 0.70 .

\section{Data Analysis}

\section{Table1: Data Analysis}

\begin{tabular}{|l|l|}
\hline RQ: & Analysis \\
\hline Q1: Which are the most useful strategies & Descriptive analysis \\
that students based on to deal with literary \\
texts of their bachelor syllabus in order to \\
have the best reading comprehension?
\end{tabular}

\section{Findings and Discussion}

This chapter discusses the findings testified in the present study in details depending on the following:

\section{Research Question One}

What are the most usable strategies that English language and literature students used to cope up with the difficulties of reading literary text?

Table2: Usable Strategies by Students

\begin{tabular}{|l|l|l|}
\hline The strategy & Frequencies & Percentage \\
\hline Cooperative learning & 106 & $88 \%$ \\
\hline Group work & 78 & $65 \%$ \\
\hline Illustration & 94 & $78,4 \%$ \\
\hline
\end{tabular}




\begin{tabular}{|l|l|l|}
\hline Extensive reading & 12 & $10 \%$ \\
\hline Critical thinking & 37 & $30 \%$ \\
\hline Cultural model & 82 & $68 \%$ \\
\hline Personal growth model & 120 & $100 \%$ \\
\hline Active learning & 34 & $20 \%$ \\
\hline Intensive reading & 102 & $85 \%$ \\
\hline
\end{tabular}

Table 2 shows that the most useful strategy to deal with literary texts is the personal growth model which has $(100 \%)$ followed by the cooperative learning strategies $(88 \%)$, illustration $(78,4 \%)$, then the cultural model $(68 \%)$ and finally group works.

\section{Cooperative Learning Strategies}

The most important strategies students of English language and literature used to read the literary texts are related to issues of literary reading such as motivation and text selecting. Regarding the strategy of acting the plays, the findings show that the majority of students agree that acting the plays helps them understand drama effectively. Based on this, it is concluded that this strategy is helpful to students studying English literature at Jordan universities and can be recommended to be the vehicle of reading to all students studying English literature in different universities in Jordan. Hammar (2014) indicate that most of the students' experiences involved group work that facilitated learning, especially in the area of academic knowledge which served as an effective pedagogy and as an incentive strategy for learning. Ramadhanti and Yanda(2018) argued that cooperative learning which based on teams is the most effective strategy in understanding poetry.

\section{Critical Thinking}

Not all students use the strategy of linking the contents of literary works with their prior knowledge and with texts written in their mother tongue. 82 students out of 120 think that knowledge acquired through learning about foreign culture and ideology help understand the plot and the theme of the foreign piece of literature. This clarifies the cause behind all of the problems which students used to face. As indicated by O'Reilly, Wang and Sabatini (2019) the background knowledge plays a key role in students' reading comprehension, if students don't have sufficient related knowledge, they'll probably have difficulties understanding text. So, lecturers must help their student connecting their previous knowledge to the present material of literature using critical thinking strategies. similarly, Fahim and Barjesteh(2018) also stated that critical thinking skills significantly affected EFL learners' reading comprehension performance.

\section{Active Learning Strategies}

The reciprocal question technique is also a helpful strategy in foreign language learning, which is considered one of the active learning strategies, where a unique questioning format that switches back and forth between the teacher and students is used. This is accomplished by firstly, the students asking their teachers questions, and then the teacher asks his/her students' questions. Finally, the answers of respondents strongly indicate that the continuous reading and re-reading of a given piece of foreign literature ends in obtaining the right and correct information by the reader. It is obvious that this strategy is very helpful as clearly illustrated in Moneus (2018) who concluded that most of the students seem to benefit from using reciprocal teaching strategy in teaching literature that might affect their performance and achievement in the reading comprehension test, or the learning process as a whole. 


\section{Intensive Reading}

Another strategy of concern to the majority of students is that literary works assigned with tasks and activities develop students' reading skills and comprehension level of these texts shall rise, and comprehension will be better than that of the text without activities and tasks assigned with them. These results strongly support the fact that intensive reading is one of the best strategies that can enhance reading pieces of foreign literature.

\section{Personal Growth Model}

The personal growth model found a wide acceptance among English language and literature students at University of Jordan. It is clearly indicated that the strategy of engagement with the piece of literature would end in making the reader having more pleasure and comprehension. This is the only strategy on which $100 \%$ of respondents agree. Therefore, involvement in reading would be one of the best strategies that students should use and must be encouraged by lecturers.

This strategy is a personal use strategy that depends on the reader own interest and involvement within the events of the literary text. That makes fast understanding of the events, theme, plot and figurative language because the learner brings all the text's details to his imagination and mind visualization, which help to gain a full connection of all text elements together.

\section{Research Question Two}

- Are there any statistically significant differences between male and female in their use of the mentioned strategies in order to achieve the best reading comprehension of their bachelor syllabus literary texts?

Table3: Independent Samples Test

Levene's Test

for Equality of

Variances t-test for Equality of Means

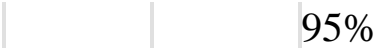

\begin{tabular}{|c|c|c|c|c|c|c|c|c|c|}
\hline & & & & & Sig. & $\begin{array}{l}\text { Mean } \\
\text { (2-Differen }\end{array}$ & $\begin{array}{l}\text { Std. } \\
\text { Error } \\
\text { Differen }\end{array}$ & $\begin{array}{l}95 \% \\
\text { Confiden } \\
\text { Interval } \\
\text { Differen }\end{array}$ & $\begin{array}{l}\text { nce } \\
\text { of the } \\
\text { ce }\end{array}$ \\
\hline & $\mathrm{F}$ & Sig. & $\mathrm{T}$ & Df & tailed) & ce & ce & Lower & Upper \\
\hline $\begin{array}{l}\text { Acting the plays helpsEqual } \\
\text { me completely tovariances } \\
\text { understand the drama.assumed }\end{array}$ & .541 & .463 & $-.149-$ & 117 & .882 & -.02599 & -.17408 & $-.37075-$ & .31877 \\
\hline $\begin{array}{ll}\text { (Cooperative } & \text { Equal } \\
\text { learning) } & \text { variances not } \\
& \text { assumed } \\
\end{array}$ & & & $-.149-$ & $\begin{array}{l}113.5 \\
97\end{array}$ & .882 & -.02599 & -.17431 & $-.37132-$ & .31934 \\
\hline $\begin{array}{l}\text { Discussing a piece ofEqual } \\
\text { literature in smallvariances } \\
\text { groups allows me toassumed }\end{array}$ & 2.643 & .107 & - & 117 & .311 & -.24379 & -.23970 & $-.71850-$ & .23093 \\
\hline $\begin{array}{l}\text { try to analyze the text.Equal } \\
\begin{array}{ll}\text { (Group work) } & \text { variances not } \\
\text { assumed }\end{array} \\
\end{array}$ & & & $\overline{-}$ & $\begin{array}{l}115.2 \\
45\end{array}$ & .312 & -.24379 & -.23992 & $-.71901-$ & .23144 \\
\hline $\begin{array}{l}\text { I prefer literary worksEqual } \\
\text { contain illustrations tovariances } \\
\text { assumed }\end{array}$ & .791 & .376 & 1.209- & 117 & .229 & $-.19944-$ & -.16492 & $-.52605-$ & .12718 \\
\hline
\end{tabular}




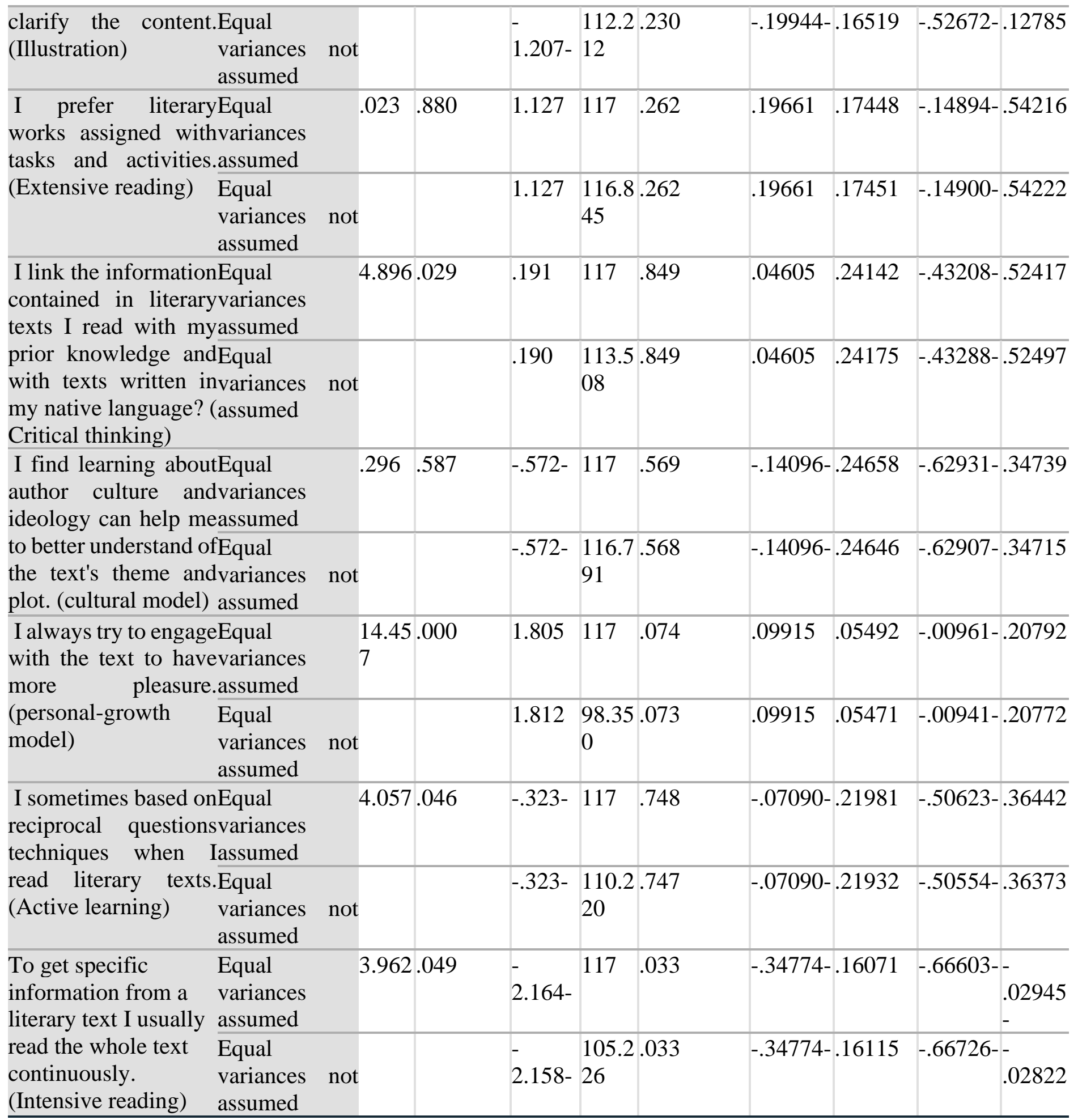

Table4: T-Test Of Using Strategies

Reading literary texts

\begin{tabular}{llllll} 
strategies & Sex & N & Mean & Std. Deviation & Std. Error Mean \\
\hline Acting
\end{tabular}

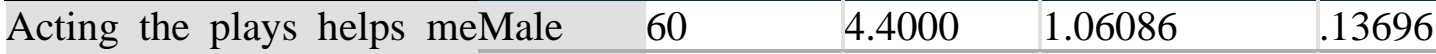

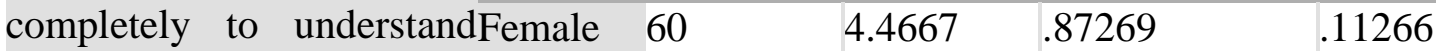

the drama. (Cooperative

learning) 


\begin{tabular}{|c|c|c|c|c|}
\hline Discussing a piece ofMale & 60 & 3.4000 & 1.38025 & .17819 \\
\hline $\begin{array}{l}\text { literature in small groupsFemale } \\
\text { allows me to try to analyze } \\
\text { the text. (Group work) }\end{array}$ & 60 & 3.6167 & 1.23634 & .15961 \\
\hline I prefer literary worksMale & 60 & 4.0500 & .98161 & .12673 \\
\hline $\begin{array}{l}\text { contain illustrations toFemale } \\
\text { clarify the content. } \\
\text { (Illustration) }\end{array}$ & 60 & 4.2333 & .81025 & .10460 \\
\hline I prefer literary worksMale & 60 & 1.8000 & .95314 & .12305 \\
\hline $\begin{array}{l}\text { assigned with } \begin{array}{l}\text { tasks andFemale } \\
\text { activities. } \\
\text { reading) }\end{array} \\
\text { (Extensive } \\
\end{array}$ & 60 & 1.6000 & .94241 & .12166 \\
\hline I link the informationMale & 60 & 2.7333 & 1.42456 & .18391 \\
\hline $\begin{array}{l}\text { contained in literary texts IFemale } \\
\text { read with my prior } \\
\text { knowledge and with texts } \\
\text { written in my native } \\
\text { language? } \\
\text { thinking) } \\
\text { (Critical }\end{array}$ & 60 & 2.7167 & 1.20861 & .15603 \\
\hline I find learning about authorMale & 60 & 3.5667 & 1.30665 & .16869 \\
\hline $\begin{array}{l}\text { culture and ideology canFemale } \\
\text { help me to better understand } \\
\text { of the text's theme and plot. } \\
\text { (cultural model) }\end{array}$ & 60 & 3.6833 & 1.38383 & .17865 \\
\hline $\begin{array}{l}\text { I always try to engage withMale } \\
\text { the text to have more }\end{array}$ & 60 & 4.9500 & .21978 & .02837 \\
\hline $\begin{array}{l}\text { pleasure. (personal-growthFemale } \\
\text { model) }\end{array}$ & 60 & 4.8500 & .36008 & .04649 \\
\hline $\begin{array}{ll}\text { I sometimes } & \text { based onMale } \\
\text { reciprocal } & \text { questions }\end{array}$ & 60 & 2.7167 & 1.04300 & .13465 \\
\hline $\begin{array}{l}\text { techniques when } \begin{array}{l}\text { I readFemale } \\
\text { literary texts. } \\
\text { learning) }\end{array} \\
\text { letive }\end{array}$ & 60 & 2.8167 & 1.34658 & .17384 \\
\hline $\begin{array}{l}\text { To get specific informationMale } \\
\text { from a literary text I usually }\end{array}$ & 60 & 4.1333 & .99943 & .12903 \\
\hline $\begin{array}{l}\text { read the whole textFemale } \\
\text { continuously. (Intensive } \\
\text { reading) }\end{array}$ & 60 & 4.4833 & .72467 & .09355 \\
\hline
\end{tabular}

Applying T-test of independent groups is used to determine the impact of gender on the use of cooperative learning, active learning, group work, Illustration, extensive reading, intensive reading, critical thinking, cultural model and personal growth model strategies. Normally, students use the strategies mentioned above to overcome difficulties confronting them when reading English literature. There is a significant difference in using critical thinking and personal growth model, whereas in using cooperative learning, active learning, group work, Illustration, extensive reading, intensive reading and cultural model strategies there is no significant difference between males and females. Based on the findings, it is clear that both 
genders have the same attitudes regarding the strategies used to enhance reading and comprehension.

Considering T-test, there are no significant differences between males' and females' usage of the mentioned strategies (cooperative learning, group work, illustration, extensive reading, cultural model, Active learning, Intensive reading) to help them understand literary texts better, but it is obvious that there is a statistically significant difference between both males and females use of the critical thinking and personal growth model in their usual reading. Since respondents have different attitudes regarding critical thinking and personal growth model, lecturers and syllabus designers should look for the reasons behind these differences. Therefore, using both critical thinking and the personal growth model has impacted students' comprehension.

\section{Conclusion}

The findings show that the most usable strategies were personal growth model, cooperative learning, intensive reading, illustration, cultural model, but that doesn't mean those are the most effective on reading ability. It was found that there are only significant differences in the use of the critical thinking strategy and the personal growth model, but there aren't any significant differences in the use of the other mentioned strategies.

\section{References}

Al-Ghazo, A. (2016). The Effect of Explicit Instruction of Meta Cognitive Learning Strategies on Promoting Jordanian Language Learners' Reading Competence. Journal of Education and Practice, 7(10), 170-177.

Almutairi, N. R. (2018). Effective Reading Strategies for Increasing the Reading Comprehension Level of Third-Grade Students with Learning Disabilities.

Fahim, M., \&Barjesteh, H. (2018). CRITICAL THINKING: A STUDY OF IRANIAN EFL READING COMPREHENSION PERFORMANCE. LEKSIKA, 5(2).

Fujino, K.(2017). Studying and Teaching W.C. Falkner, William Faulkner, and Digital Literacy: Personal Democracy in Social Combination. Lexington Books.

Qamar, F. (2016). Effectiveness of Critical Thinking Skills for English Literature Study with Reader Response Theory: Review of Literature. Journal of Arts and Humanities, 5(6), 37-50.

Gray, W. D., \& Schunn, C. D. (Eds.). (2019). Proceedings of the twenty-fourth annual conference of the cognitive science society. Routledge.

Gilakjani, A.P., \& Sabouri, N.B. (2016). Learners' Listening Comprehension Difficulties in English Language Learning: A Literature Review, English Language Teaching, 9 (6), 123-133.

HammarChiriac, E. (2014). Group work as an incentive for learning-students' experiences of group work. Frontiers in psychology, 5, 558.

Hurriyah, S. (2017). INTENSIVE READING PRACTICE ON NARRATIVE TEXT AT MA BINA CENDEKIA CIREBON (Doctoral dissertation, IAIN Syekh Nurjati Cirebon).

Kuru-Gonen, I. (2015: 2924-2636). The relationship between FL reading strategies and FL reading proficiency: A study on Turkish EFL learners. Academic Journals. Retrieved from http://www.academicjournals.org/ERR .

Marashi, H., \&Rahmati, P. (2017). The effect of teaching reading strategies on EFL learners' reading anxiety. International Journal of Research in English Education, 2(2), 43-52.

Moneus, A. M. A. (2018). The Impact of Reciprocal Teaching for Literature Courses on Fostering Students' Reading Comprehension at Yemeni Universities (Doctoral dissertation, Sana'a University). 
Okkinga, M., Steensel, R., Gelderen, A. J., \&Sleegers, P. J. (2018). Effects of reciprocal teaching on reading comprehension of low-achieving adolescents. The importance of specific teacher skills. Journal of Research in Reading, 41(1), 20-41.

O'Reilly, T., Wang, Z., \& Sabatini, J. (2019). How much knowledge is too little? When a lack of knowledge becomes a barrier to comprehension. Psychological science, 30(9), 13441351.

Ramadhanti, D., \&Yanda, D. P. (2018). Understanding poetry through the use of cooperative learning model. Cakrawala Pendidikan.

Taber, Keith. (2017). The Use of Cronbach's Alpha When Developing and Reporting Research Instruments in Science Education. Research in Science Education. 1-24. 10.1007/s11165-016-9602-2. 